Pak. J. Agri., Agril. Engg., Vet. Sci., 2021, 37 (1): 11-20

ISSN: 1023-1072 (Print), ISSN: 2663-7863 (Online)

https://doi.org/10.47432/2020.37.1.2

\title{
STANDARDIZATION OF DOSES OF PHOSPHORUS AND POTASIUM ON GROWTH AND FRUIT QUALITY OF YOUNG KINNOW (CITRUS RETICULATE BLANCO)
}

\author{
Amina $^{1}$, M. Z. Rashid ${ }^{* 1}$, M. Asim ${ }^{2}$, S. Shahzad ${ }^{4}$ and S. Muqeet ${ }^{3}$ \\ ${ }^{1}$ Horticultural Research Institute, Faisalabad, Pakistan \\ ${ }^{2}$ Citrus Research Institute, Sargodha, Pakistan \\ ${ }^{3}$ Directorate of Pest Warning and Quality Control of Pesticides, Pakistan \\ ${ }^{4}$ Institute of Horticultural Sciences, University of Agriculture, Faisalabad, Pakistan
}

\begin{abstract}
Plants require a balanced nutrition program formulated to provide specific needs for maintenance and for expected production performance. Hence this experiment was conducted to evaluate the optimum level of phosphorus and potassium for growth and productivity of young Kinnow (Citrus reticulata Blanco) plants. The experiment was designed under Randomized Complete Block Design (RCBD) comprised with seven treatments and replicated thrice. The treatments included, $\mathrm{T}_{1}=200 \mathrm{~g} \mathrm{P}_{2} \mathrm{O}_{5}+200$ $\mathrm{g} \mathrm{K}_{2} \mathrm{O}, \mathrm{T}_{2}=150 \mathrm{~g} \mathrm{P}_{2} \mathrm{O}_{5}+200 \mathrm{~g} \mathrm{~K}_{2} \mathrm{O}, \mathrm{T}_{3}=250 \mathrm{~g} \mathrm{P}_{2} \mathrm{O}_{5}+200 \mathrm{~g} \mathrm{~K}_{2} \mathrm{O}, \mathrm{T}_{4}=300 \mathrm{~g} \mathrm{P}_{2} \mathrm{O}_{5}+200 \mathrm{~g} \mathrm{~K}_{2} \mathrm{O}, \mathrm{T}_{5}=$ $250 \mathrm{~g} \mathrm{P}_{2} \mathrm{O}_{5}+150 \mathrm{~g} \mathrm{~K}_{2} \mathrm{O}, \mathrm{T}_{6}=200 \mathrm{~g} \mathrm{P}_{2} \mathrm{O}_{5}+250 \mathrm{~g} \mathrm{~K}_{2} \mathrm{O}$ and $\mathrm{T}_{7}=200 \mathrm{~g} \mathrm{P}_{2} \mathrm{O}_{5}+300 \mathrm{~g} \mathrm{~K}_{2} \mathrm{O}$. Maximum plant height $(3.12 \mathrm{~m})$ and Juice $(43.48 \%)$ was observed in $\mathrm{T}_{5}=250 \mathrm{~g} \mathrm{P}_{2} \mathrm{O}_{5}+150 \mathrm{~g} \mathrm{~K} \mathrm{O}_{2}$. The highest number of flush (33.08), number of leaves $\left(101.25 \mathrm{~m}^{2}\right)$, length of flush $(13.75 \mathrm{~cm})$, Seed weight $(1.33$ g), Aborted seeds/fruit (8), mature seed fruit (5.48) were noted in $T_{7}$. Leaf area index and peel thickness were significantly increased in $\mathrm{T}_{6}=\left(200 \mathrm{~g} \mathrm{P}_{2} \mathrm{O}_{5}+250 \mathrm{~g} \mathrm{~K}_{2} \mathrm{O}\right)$ with values $1.91 \mathrm{~cm}^{3}$ and 4.30 $\mathrm{mm}$ respectively. So, it is concluded that $\mathrm{T}_{5}=250 \mathrm{~g} \mathrm{P}_{2} \mathrm{O}_{5}+150 \mathrm{~g} \mathrm{~K}_{2} \mathrm{O}$ and $\mathrm{T}_{7}=200 \mathrm{~g} \mathrm{P}_{2} \mathrm{O}_{5}+300 \mathrm{~g} \mathrm{~K}_{2} \mathrm{O}$ is the best treatments for the growth and better yield of young Kinnow plants.
\end{abstract}

Keywords: citrus, fertilizer, kinnow, phosphorus, potassium, young plants

\section{INTRODUCTION}

Kinnow (Citrus reticulata Blanco) is a main fruit among citrus group and is liked by all type of people due to its outstanding flavor, nutritional values, rich in vitamin- $C$ and more juice contents (Khan et al., 2016). Citrus is the important fruit crop of Pakistan relative to area, yield and export. It provides 95\% stake of annual citrus exports from Pakistan (Tahir et al., 2014). Pakistan is at $13^{\text {th }}$ number with production of 2.35 million tons and area of 1.84 thousand hectare (Anonymous, 2018-19).

Share of Punjab province is the highest due to its climate (Niaz, 2004). Sargodha, Sahiwal and Toba Tek Singh are the main citrus producing districts in Punjab. At this point Sargodha is the leading citrus producing district, with almost 23 percent of Pakistan's total citrus plantings (Niaz, 2004). However, the demand of Pakistan Kinnow fruit is more than as compared to other mandarin group member, however our exporting potential is merely $8 \%$ due to large portion going waste due to infertile soil, poor fertilizer management practices, poor management during harvesting, transportation, packaging and storage (Amina et al., 2018).

Plant nutrient management can impact on plant characteristics like flowering, fruit set, fruit size and the volume of vegetative growth. By wisely picking the constituents of fertilizer programme, the farmer can encourage the crop toward earlier and heavy fruit setting (Ibrahim et al., 2004; Abd-Allah, 2006). The balanced nutrition has been paid less consideration in agricultural areas of the developing world. Nutrients are significant for plant growth and development. (Alva et al., 2006).

"Corresponding author: uafzahid@gmail.com 
The macro-nutrients particularly nitrogen $(\mathrm{N})$, phosphorus $(\mathrm{P})$ and potassium $(\mathrm{K})$ are required by the citrus plant in higher amount than any other crop. They plays a vital role in yield, along with fruit quality (Albrigo, 2002; Storey et al., 2002; Srivastava et al., 2009; Hammami et al., 2010; Lester et al., 2010; Liu et al., 2010). Phosphorus performs various vigorous functions in the plant photosynthesis, enzyme activity, metabolism and movement of sugars (Davies et al., 1994b). Minimum phosphorous contents in leaves have been described to produce misshaped poor quality Kinnow mandarin fruit along open centers, rough and thickened peel and low acidity in juice (Raza et al., 1999). Citrus fruit tree takes up more amount of potassium (K) compared to other macronutrients (Ashraf et al., 2010; 2012). Since it has an important part in many key physical processes like water relations, opening and closing of stomata, cell division, formation of sugars and starch, neutralization of organic acids, making of proteins, and activation of enzymes (Liu et al., 2000; Srivastava et al., 2006). Potassium increases citrus fruit quality by improving fruit size, juice contents, color, size and juice flavor (Tiwari, 2005; Ashraf et al., 2010). So, inadequate quantity of $K$ may affect the yield and quality of citrus fruit and quicken the fruit dropping. The $K$ plays a regulatory role in physiological and bio-chemical processes of citrus plant (Davies et al., 1994a). The K application has also been described to show significant role in the acid metabolism of the citrus juice (Achilea et al., 2002).

The development of young trees is more speedy as compared to fruiting tree, so the amount of macronutrients is more essential to accomplish the requirement of these fast growing trees and growth. But commonly research has been showed everywhere in the world on mature citrus trees hence there is a dire need to evaluate the outcomes of macronutrients ( $\mathrm{P}$ and $\mathrm{K}$ ) on young citrus trees on growth, fruit quality and yield (Obreza., 2001). This experiment was directed to determine the fertilizer application program for young plants. The main aim of experiment were to enhance doses of $P$ and $K$ for young citrus plants, regulate the response of various doses of Phosphorus and Potassium application on yield and yield contributing factors and to analysis the effect of different doses of phosphorus and potassium on fruit quality.

\section{MATERIALS AND METHODS}

This study was conducted at the research area of Horticultural Research Institute, Ayub Agricultural Research Institute $\left(31.42^{\circ} \mathrm{N}\right.$, $73.09^{\circ} \mathrm{E}$ longitude, altitude $189 \mathrm{~m}$ ) Faisalabad Pakistan during year 2017-2019. This area falls in a sub-tropical zone, with warm summer and moderate winter. Approximately $18.88 \mathrm{~mm}$ rainfall throughout cropping duration along with relative humidity of $29.07 \%$. Average maximum and minimum temperature throughout the cropping season were $36.46^{\circ} \mathrm{C}$ and $28.46^{\circ} \mathrm{C}$, respectively. The soil was loamy in texture, alkaline (8.1) in reaction and low in organic matter $(0.86 \%)$. The research was carried out on five years old Kinnow mandarin plants grafted on rough lemon rootstock. During the course of experiment, cultural practices such as weeding, hoeing, irrigation, fertilization and insect pest management were done where and when needed. The trees were applied with the recommended doses of nitrogen fertilizer into three split doses to maintain the plant vigor and the growth. The soil application of fertilizers was done in February with dose of nitrogen and rest of doses were applied in April and September.

The research was carried out on five years old Kinnow mandarin (Citrus reticulata Blanco.) plants grafted on rough lemon rootstock. The experiment consisted of the following treatments replicated thrice.

$\mathrm{T}_{1}=200 \mathrm{~g} \mathrm{P}_{2} \mathrm{O}_{5}+200 \mathrm{~g} \mathrm{~K}_{2} \mathrm{O}$
$\mathrm{T}_{2}=150 \mathrm{~g} \mathrm{P}_{2} \mathrm{O}_{5}+200 \mathrm{~g} \mathrm{~K}_{2} \mathrm{O}$
$\mathrm{T}_{3}=250 \mathrm{~g} \mathrm{P}_{2} \mathrm{O}_{5}+200 \mathrm{~g} \mathrm{~K}_{2} \mathrm{O}$
$\mathrm{T}_{4}=300 \mathrm{~g} \mathrm{P}_{2} \mathrm{O}_{5}+200 \mathrm{~g} \mathrm{~K}_{2} \mathrm{O}$
$\mathrm{T}_{5}=250 \mathrm{~g} \mathrm{P}_{2} \mathrm{O}_{5}+150 \mathrm{~g} \mathrm{~K}_{2} \mathrm{O}$
$\mathrm{T}_{6}=200 \mathrm{~g} \mathrm{P}_{2} \mathrm{O}_{5}+250 \mathrm{~g} \mathrm{~K}_{2} \mathrm{O}$
$\mathrm{T}_{7}=200 \mathrm{~g} \mathrm{P}_{2} \mathrm{O}_{5}+300 \mathrm{~g} \mathrm{~K}_{2} \mathrm{O}$

\section{Morphological parameters Plant height (m)}

Plant height was measured in meters with the measuring pole by placing the pole close to the tree. The initial reading was taken in the month of January 2017 and the final reading was in the month of January 2018. The difference between initial and the final reading was taken as the increased height in response to the treatment application.

\section{Plant spread ( $\mathrm{m})$}

The plant spread was measured in meters by two way observations from North-South and East-West with the measuring tape. Their mean values were considered as the actual spreading of the tree. 
Plant canopy volume $\left(\mathrm{m}^{3}\right)$

Plant canopy volume (CV) was calculated using the following formula after measuring the outer peripheral branches of the plant canopy in EastWest and North-South directions (Smit, 2008).

Canopy Volume $=\mathrm{H} \times \mathrm{S}^{2} \times 0.3852$

Where $\mathrm{H}=$ Plant height, $\mathrm{S}=$ Plant Spread

Stock-scion ratio $(\mathrm{cm})$

Vernier caliper was used for measurement of stock-scion girth at 2 inches above the graft union of $\mathrm{R} / \mathrm{S}$.

\section{Number of new leaves per flush}

Total number of new leaves or nodes were counted on each tagged flush in both active growth seasons i.e., spring and autumn.

\section{Number of flushes per $\mathbf{m}^{2}$}

Total number of flushes were counted in both active growth seasons spring and autumn. The data was taken by counting the total number of new flushes per square meter from four sides of the tree.

\section{Length of new flushes (cm)}

Five new flushes were tagged per square meter from four sides of tree and their mean values were calculated.

\section{Leaf Area Index}

For calculating LAI, leaves were collected from four sides of the plant per treatment and measured by using leaf area meter ( $\mathrm{Cl}-203$ Leaf Area Meter Inc. Japan).

$\mathrm{LAI}=\frac{\text { Leaf area }}{\text { Surface area }}$

\section{Fruit weight (g)}

Fruit weight was calculated by taking 10 fruits per treatment on digital electric balance and average was calculated in grams.

\section{Fruit size (mm)}

Fruit size of sampled fruit was measured in millimeter with the help of digital Vernier caliper and the average was taken.

\section{Peel thickness ( $\mathrm{mm}$ )}

Peel thickness was calculated in millimeter by using digital Vernier caliper for sampled fruits.

Rag (membranes and cores) \% Rag\% was calculated by the following formula in percentage (Umar.M. et al., 2017)

$$
\begin{aligned}
& \text { Rage } \%=\frac{\text { Average peel weight of fruit }(\mathrm{gm})}{\text { Average fruit weight }(\mathrm{gm})} \times 100 \\
& \text { Juice } \% \\
& \text { Juice weight percentage was calculated by } \\
& \text { using the following formula: } \\
& \text { Juice weight } \%=\frac{\text { Average juice weight }(\mathrm{gm})}{\text { Average fruit weight }(\mathrm{gm})} \times 100
\end{aligned}
$$

\section{Number of seeds per fruit}

To count the total number of seeds per sampled fruit, five fruits were taken as a sample from each side of the tree of the respective treatment. Average weight of seed per fruit Weight all the seed in representative fruit sample and were averaged. Weighing unit of seed were expressed in grams.

\section{Average number of mature and aborted seeds per fruit}

Mature as well as aborted seeds of each fruit were counted sample wise and was averaged.

\section{Statistical Design and Analysis}

The data was analyzed by using software (version 8.1) through Randomized Complete Block Design (RCBD) to obtain analysis of variance (ANOVA). Means of all treatments were compared pair wise by lest significant difference test (LSD) and significance was tested at $5 \%$ significance level.

\section{RESULTS AND DISCUSSION}

Plant height

Our results indicated that effect of phosphorus and potassium on plant height was nonsignificant. Plant height was taken into consideration to determine the role of different levels of phosphorus and potassium on the vegetative performance of the tree. Although results were non-significant but maximum plant height $3.12 \mathrm{~m}$ was observed in $\mathrm{T}_{5}\left(250 \mathrm{~g} \mathrm{P}_{2} \mathrm{O}_{5}+\right.$ $150 \mathrm{~g} \mathrm{~K}_{2} \mathrm{O}$ ) whereas, minimum plant height 2.96 $\mathrm{m}$ was shown in $\mathrm{T}_{4}\left(300 \mathrm{~g} \mathrm{P}_{2} \mathrm{O}_{5}+200 \mathrm{~g} \mathrm{~K}_{2} \mathrm{O}\right)$.

Shirgure et al. (2013) found that biometric growth parameters of Nagpur mandarin revealed that out of various growth parameters, plant height produced a non-significant effect in relation to $P$ and $K$ treatments. Same results of plant height were found in close consonance with (Ahmed et al., 2001; Dudi et al., 2007; Barak et al., 2012) they studied similar results.

\section{Plant spread (m)}

Results of plant spread was revealed nonsignificant. Maximum plant spread $(2.61 \mathrm{~m})$ was 
observed in $\mathrm{T}_{1}\left(200 \mathrm{~g} \mathrm{P}_{2} \mathrm{O}_{5}+200 \mathrm{~g} \mathrm{~K}_{2} \mathrm{O}\right)$ followed by $\mathrm{T}_{5}\left(250 \mathrm{~g} \mathrm{P}_{2} \mathrm{O}_{5}+150 \mathrm{~g} \mathrm{~K}_{2} \mathrm{O}\right)$ showed $2.44 \mathrm{~m}$. While minimum $(2.18 \mathrm{~m})$ plant spread was found in $\mathrm{T}_{2}\left(150 \mathrm{~g} \mathrm{P}_{2} \mathrm{O}_{5}+200 \mathrm{~g} \mathrm{~K}_{2} \mathrm{O}\right)$. The observations are closely related to (Dudi et al., 2007; lbe et al., 2011and Ashkevari et al., 2013) they studied the response of fertilizer $(\mathrm{P}, \mathrm{K})$ and described non-significant results in Thomson novel.

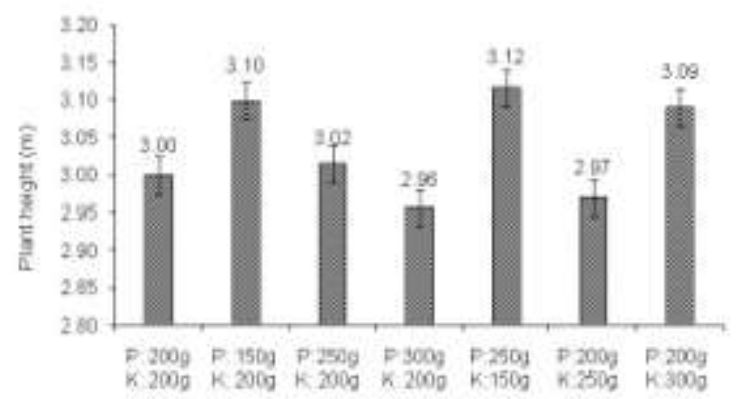

Figure 1. Effect of $P$ and $K$ on plant height of young Knnow plants

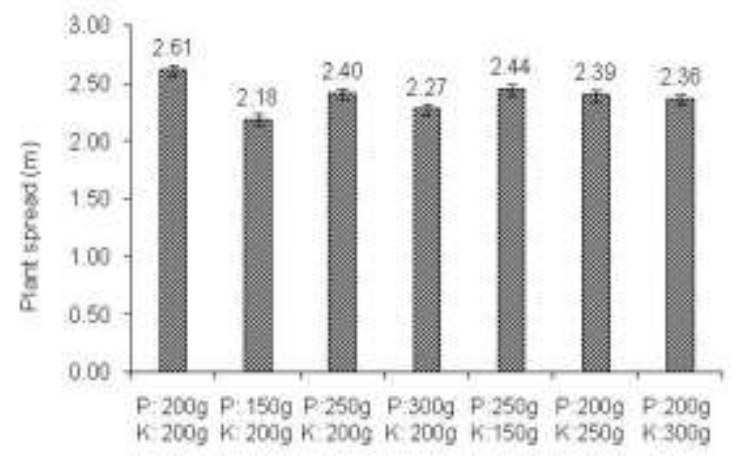

Figure 2. Effect of $P$ and $K$ on Plant spread of young Kinnow Plants

\section{Plant canopy $\left(\mathrm{m}^{3}\right)$}

The efficiency of the use of nutrients and other resources by tree depends upon the tree canopy volume. Data was collected and indicated overall non-significant results among treatments as shown in (Figure 3). Statistical evaluation of the data depicted that maximum value $(10.75$ $\left.\mathrm{m}^{3}\right)$ was indicated by $\mathrm{T}_{1}\left(200 \mathrm{~g}_{2} \mathrm{O}_{5}+200 \mathrm{~g}\right.$ $\left.\mathrm{K}_{2} \mathrm{O}\right)$. While minimum value $\left(7.86 \mathrm{~m}^{3}\right)$ depicted by $\mathrm{T}_{2}\left(150 \mathrm{~g} \mathrm{P}_{2} \mathrm{O}_{5}+200 \mathrm{~g} \mathrm{~K}_{2} \mathrm{O}\right)$.

Our results are confirmed the findings of Shirgure et al. (2013) reported that canopy of plant showed non-significant results in Nagpur mandarin plant. The results of the present investigation are in line with the findings of Barakat et al. (2012) in Naval orange Obreza
(2001) in Grape fruit and lbe et al., (2000) in sweet orange.

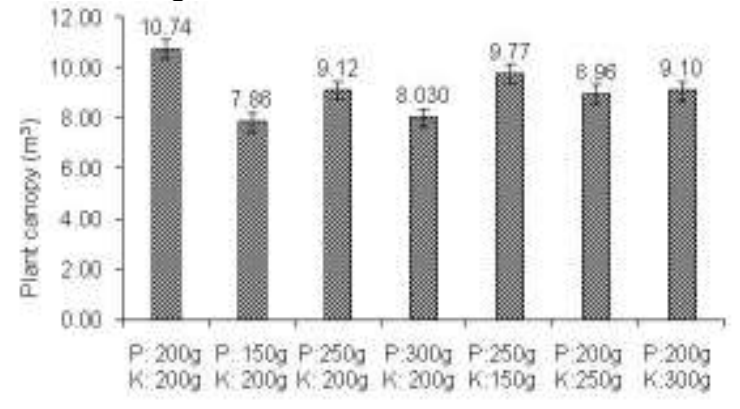

Figure 3. Effect of $\mathrm{P}$ and $\mathrm{K}$ on Plant Canopy of young Kinnow

\section{Stock scion girth ratio $(\mathrm{cm})$}

Stock scion girth reflected the most responsible index of tree vigor. Results indicated that there was no overall significant effect of phosphorus and potassium on stock scion girth ratio. Resultantly the $\mathrm{T}_{1}\left(200 \mathrm{~g} \mathrm{P}_{2} \mathrm{O}_{5}+200 \mathrm{~g} \mathrm{~K}_{2} \mathrm{O}\right)$ with value show highest stock scion girth ratio (1.09 $\mathrm{cm})$. Lowest plant canopy $(0.95 \mathrm{~cm})$ was seen in $\mathrm{T}_{2}$ (150g $\mathrm{P}_{2} \mathrm{O}_{5}+200 \mathrm{~g} \mathrm{~K} \mathrm{O}$ ). Our results confirmed the findings of Shirgure et al. (2013) reported that effect of phosphorus and potassium non-significant on the stockscion girth. Ahmed et al. (2001) concluded that different levels of phosphorus and potassium clearly showed non-significant results regarding citrus plant girth.

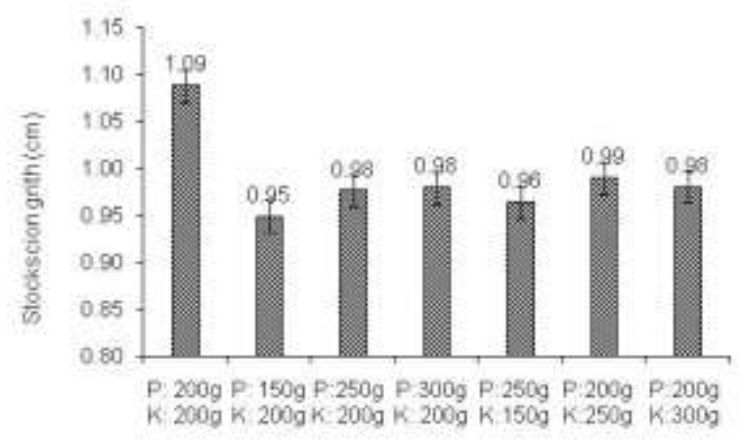

Figure 4. Effect of $\mathrm{P}$ and $\mathrm{K}$ stockscion girth on young Kinnow plants

\section{Number of flushes per $\mathrm{m}^{2}$}

The data indicates that phosphorus and potassium had a significant effect on the number of new flushes among all treatments. It was examined that maximum value $33.08 \mathrm{~m}^{2}$ was found in $\mathrm{T}_{7}\left(200 \mathrm{~g} \mathrm{P}_{2} \mathrm{O}_{5}+300 \mathrm{~g} \mathrm{~K}_{2} \mathrm{O}\right)$, followed by $31.29 \mathrm{~m}^{2} \mathrm{~T}_{6}\left(200 \mathrm{~g} \mathrm{P}_{2} \mathrm{O}_{5}+250 \mathrm{~g} \mathrm{~K} \mathrm{~K}_{2} \mathrm{O}\right)$. While 
minimum no. of flushes $\left(24.67 \mathrm{~m}^{2}\right)$ recorded in $\mathrm{T}_{3}\left(250 \mathrm{~g} \mathrm{P}_{2} \mathrm{O}_{5}+200 \mathrm{~g} \mathrm{~K}_{2} \mathrm{O}\right)$.

(Dudi et al., 2007; Ashkevari et al., 2013) and Smith, Cheary and Carroll (1995) studied the growth behavior of the citrus plant and found a significant interaction was detected for the number of current-season shoots produced from phosphorus application slightly increased the number of current-season shoots.

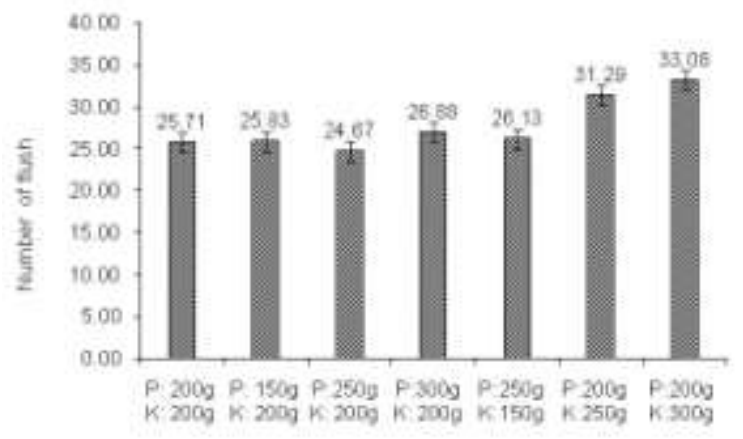

Figure 5. Effect of $\mathrm{P}$ and $\mathrm{K}$ on Number of Flush in Young Kinnow

\section{Noumber of leaves per $\mathrm{m}^{2}$ on new flushes}

Leaves are considered as the most active part as for the plant nutrient metabolism. The statistical analysis of data regarding to the number of leaves per $\mathrm{m}^{2}$ on flushes revealed highly significant results. Application of different levels of $P$ and $K$ had maximum number of leaves was observed in $\mathrm{T}_{7}\left(200 \mathrm{~g} \mathrm{P}_{2} \mathrm{O}_{5}+300 \mathrm{~g}\right.$ $\mathrm{K}_{2} \mathrm{O}$ ) with 101.25 as showed in (Figure 6). Minimum value perceived by $\mathrm{T}_{3}\left(250 \mathrm{~g} \mathrm{P}_{2} \mathrm{O}_{5}+\right.$ $200 \mathrm{~g} \mathrm{~K}_{2} \mathrm{O}$ ) depicted 65.41. (Dudi et al., 2007; Ashkevari et al., 2013) reported that phosphorus application significantly effected on number of leaves per shoot from 54.22 to 72.05 at 320 and $480 \mathrm{~g} \mathrm{P}_{2} \mathrm{O}_{5}$ per plant levels of $\mathrm{P}$ application. Similarly dose of potassium $210 \mathrm{~g}$ per plant also increased significantly number of leaves. Phosphorus is a necessary nutrient for energy production and hence can affect different plant growth parameters i.e. number of leaves and Potassium is important for water efficient use by plant and other functions including the activity of enzymes affecting plant growth.

\section{Length of flushes (cm)}

The data depicted highly significant results of length of flushes. Highest length of flushes $(13.97 \mathrm{~cm})$ was noted in $\mathrm{T}_{4}\left(300 \mathrm{~g} \mathrm{P}_{2} \mathrm{O}_{5}+200 \mathrm{~g}\right.$ $\mathrm{K}_{2} \mathrm{O}$ ) in young Kinnow plants. Moreover lowest value depicted by $\mathrm{T}_{1}\left(200 \mathrm{~g} \mathrm{P}_{2} \mathrm{O}_{5}+200 \mathrm{~g} \mathrm{~K}_{2} \mathrm{O}\right)$ showed the minimum mean value $(12 \mathrm{~cm})$ in length of flushes. Dudi et al. (2007) described that flush length significantly increased at $\mathrm{P}_{2} \mathrm{O}_{5}$ $320 \mathrm{~g}$ and $210 \mathrm{~g} \mathrm{~K} \mathrm{~K}_{2} \mathrm{O}$ application per plant of Kinnow.

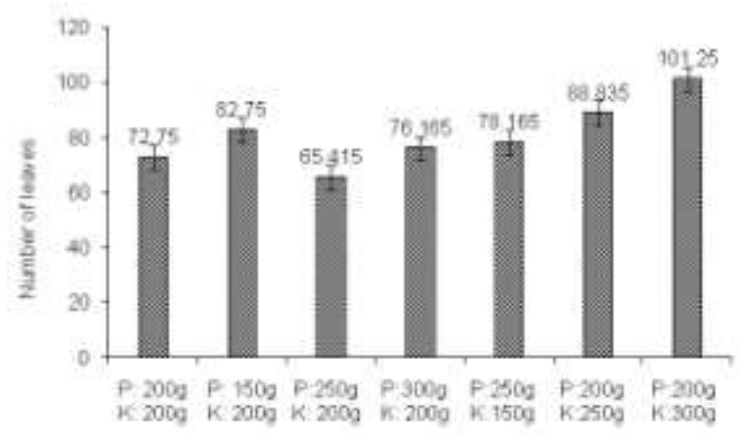

Figure 6. Effect of $\mathrm{P}$ and $\mathrm{K}$ on No. of Leaves on Young Kinnow plants

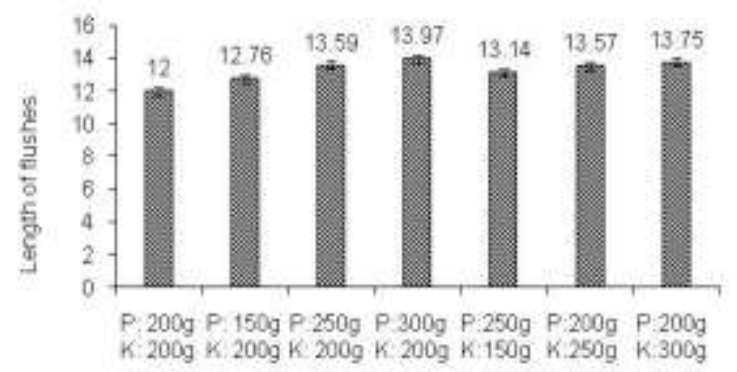

Figure7. Effect of $\mathrm{P}$ and $\mathrm{K}$ on Length of flushes of young Kinnow plants

\section{Leaf area index (LAl)}

Leaf area index results depicted significant results. Maximum leaf area index $\left(1.58 \mathrm{~cm}^{3}\right)$ was found in $\mathrm{T}_{6}\left(200 \mathrm{~g} \mathrm{P}_{2} \mathrm{O}_{5}+250 \mathrm{~g} \mathrm{~K}_{2} \mathrm{O}\right)$. Leaf area increased, because $\mathrm{K}$ enhances the rate of photosynthesis. Same results were observed Barakat et al. (2012) and described that leaf area was significantly affected by $\mathrm{K}$ fertilization dose. Lowest value of leaf area index $\left(1.26 \mathrm{~cm}^{3}\right)$ was recorded in $\mathrm{T}_{1}\left(200 \mathrm{~g} \mathrm{P}_{2} \mathrm{O}_{5}+200 \mathrm{~g} \mathrm{~K}_{2} \mathrm{O}\right)$.

Our results also confirmed the findings of Ali et al. (2004) reported that the lowest leaf area index (1.94) was observed in treatment where less phosphorus was applied. (Singh et al., 1983; Yahiya et al. 1995) have found the similar findings that leaf area index increased with application of phosphorus fertilizer.

\section{Fruit weight (g)}

According to the mean values of fruit weight ranges from 93.03-73.37g. Maximum fruit weight (93.03g) was observed in $\mathrm{T}_{1}\left(200 \mathrm{~g} \mathrm{P}_{2} \mathrm{O}_{5}+200 \mathrm{~g}\right.$ $\left.\mathrm{K}_{2} \mathrm{O}\right)$, and similarly $\mathrm{T}_{2}\left(150 \mathrm{~g} \mathrm{P}_{2} \mathrm{O}_{5}+200 \mathrm{~g} \mathrm{~K} \mathrm{~K}_{2} \mathrm{O}\right)$ 
with value $89.33 \mathrm{~g}$. While the minimum fruit weight $(73.37 \mathrm{~g})$ was found in $\mathrm{T}_{7}\left(200 \mathrm{~g} \mathrm{P}_{2} \mathrm{O}_{5}+\right.$ $300 \mathrm{~g} \mathrm{~K}_{2} \mathrm{O}$ ), which was statistically different from other treatments.

Results indicated the prominent effect of maximum $300 \mathrm{~g} /$ plant $\mathrm{K}$ application increased the fruit weight. So there should be more fruit weight if having more $\mathrm{K}$ in leaves of plant. In this context our results confirmed the findings (Dudi et al., 2007; Shirgure et al., 2013) reported that fruit weight response was non-significant to phosphorus and potassium fertilizers sources.

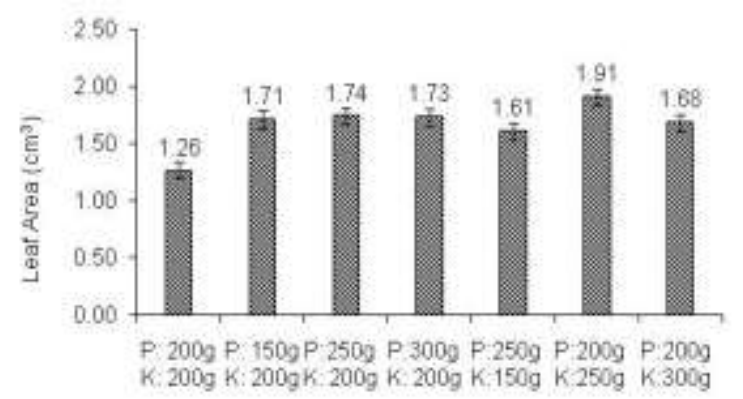

Figure 8. Effect of $P$ and $K$ on No. of Leaves on Young Kinnow plants

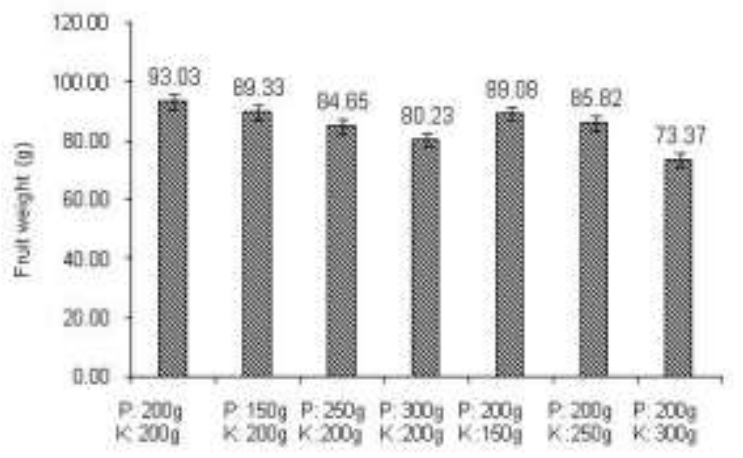

Figure 9. Effect of $\mathrm{P}$ and $\mathrm{K}$ on Number of Fruit weight on Young Kinnow plants

\section{Peel thickness (mm)}

Peel thickness is an important parameter of fruit quality and statistically data pertaining the result showed non-significant effect for peel thickness. Treatment $\mathrm{T}_{6}\left(200 \mathrm{~g} \mathrm{P}_{2} \mathrm{O}_{5}+250 \mathrm{~g} \mathrm{~K}_{2} \mathrm{O}\right)$ had the maximum peel thickness $(4.30 \mathrm{~mm})$, which was statistically different from other treatments. While $\mathrm{T}_{1}\left(200 \mathrm{~g} \mathrm{P}_{2} \mathrm{O}_{5}+200 \mathrm{~g} \mathrm{~K}_{2} \mathrm{O}\right)$ with minimum $(3.14 \mathrm{~mm})$ peel thickness values.

In this context the results confirmed the results of Zaied, Khafagy, and Saleh (2006) on Washington navel orange responses $P$ fertilization decreased rind thickness. Dubey et al. (2003) peel thickness was not affected significantly by application of potassium.

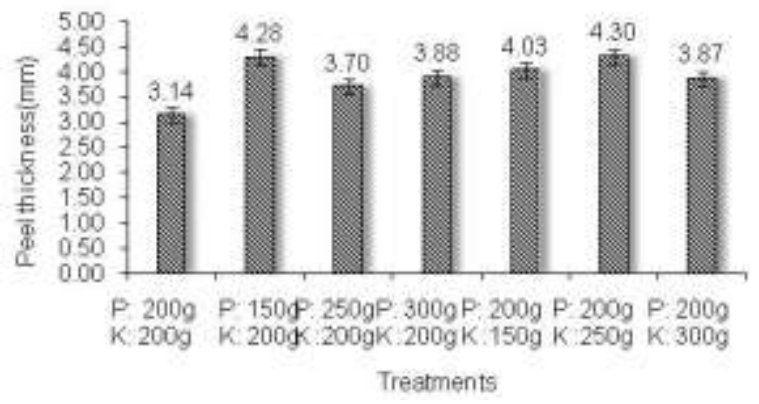

Figure 10. Effect of $P \& K$ on peel thickness of kinnow

\section{Number of seeds (seeds/fruit)}

The analysis of variance showed significant effect of phosphorus and potassium on number of seed per fruit of young plants. The perusal of (Figure 11) shows that means for number of seeds per fruit ranges from (7.73-12.33) seeds per fruit. Maximum number of seeds (12.33 seeds/fruit) were found in $\mathrm{T}_{7}\left(200 \mathrm{~g} \mathrm{P}_{2} \mathrm{O}_{5}+300 \mathrm{~g}\right.$ $\mathrm{K}_{2} \mathrm{O}$ ). Whereas, minimum value 7.73 was observed in $\mathrm{T}_{6}\left(200 \mathrm{~g} \mathrm{P}_{2} \mathrm{O}_{5}+250 \mathrm{~g} \mathrm{~K}_{2} \mathrm{O}\right)$.

Our findings were closely related with Saeed et al. (2011) they found that number of seed was significantly affected by phosphorus and potassium fertilizers.

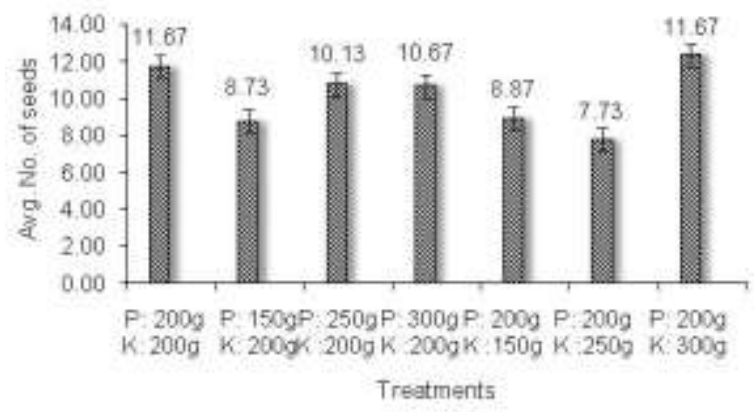

Figure 11. Effect of $\mathrm{P}$ and $\mathrm{K}$ on Avg. no. of seeds in kinnow

\section{Seed weight (g)}

Analysis of variance (Figure 12) showed nonsignificant effect of $P$ and $K$ on seed weight. Maximum seed weight $1.33 \mathrm{~g}$ was recorded in $\mathrm{T}_{7}$ $\left(200 \mathrm{~g} \mathrm{P}_{2} \mathrm{O}_{5}+300 \mathrm{~g} \mathrm{~K}_{2} \mathrm{O}\right)$, which was statistically different from other treatments. Lowest seed weight showed by $\mathrm{T}_{3}\left(250 \mathrm{~g}_{2} \mathrm{O}_{5}+200 \mathrm{~g} \mathrm{~K}_{2} \mathrm{O}\right)$ with mean value $0.29 \mathrm{~g}$.

Results showed overall non-significant effect of $P$ and $K$ on weight of seeds per fruit. Our results are confirmed findings of (Saeed et al. (2011; Ashkevari et al., 2013) concluded that 
non-significant differences were found among different levels of phosphorus and potassium for seed weight.

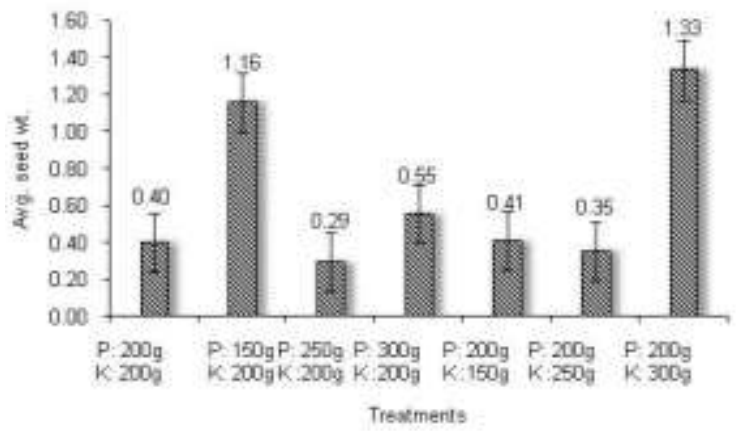

Figure 12. Effect of $P \& K$ on Avg. seed weight of kinnow

\section{Aborted seeds per fruit}

According to (Figure 13) mean values for the number of aborted seeds in kinnow mandarin ranges from 8- 1.93 seeds per fruit. The maximum number of aborted seeds (8) was observed in case of $\mathrm{T}_{7}\left(200 \mathrm{~g} \mathrm{P}_{2} \mathrm{O}_{5}+300 \mathrm{~g} \mathrm{~K}_{2} \mathrm{O}\right)$, which was statistically different from other treatments. While minimum value 1.93 shows by $\mathrm{T}_{5}\left(250 \mathrm{~g} \mathrm{P}_{2} \mathrm{O}_{5}+150 \mathrm{~g} \mathrm{~K}_{2} \mathrm{O}\right)$.

Our results confirmed the findings by (Altaf, Khan and Hussain (2008; Ashkevari et al. 2013) reported that PK effected on aborted seed significantly.

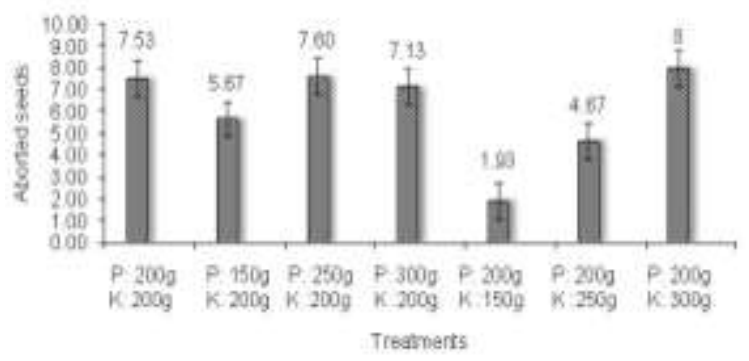

Figure 13. Effect of $P$ and $K$ on Avg. no. of aborted seeds in kinnow fruit

\section{Mature seeds per fruit}

Observations regarding the effect of $\mathrm{P}$ and $\mathrm{K}$ on the number of mature seeds in Kinnow mandarin were statistically significant as shown (Figure 14). Data showed that maximum number of mature seeds were 5.48 found in $\mathrm{T}_{7}\left(200 \mathrm{~g} \mathrm{P}_{2} \mathrm{O}_{5}\right.$ $+300 \mathrm{~g} \mathrm{~K}_{2} \mathrm{O}$ ) while lowest number of mature seeds were found in 2.53 in $\mathrm{T}_{3}\left(250 \mathrm{~g} \mathrm{P}_{2} \mathrm{O}_{5}+\right.$ $200 \mathrm{~g} \mathrm{~K}_{2} \mathrm{O}$ ). Results concluded that there is some effect of treatments on number of mature seeds in fruits. Number of healthy seeds might also be affected by nutritional imbalance, like deficiency of phosphorus can increase the seediness in fruits.

Different levels of $\mathrm{P}$ and $\mathrm{K}$ effected significantly on number of aborted of citrus. Results are confirmed the findings of (Altaf et al. (2008; Ashkevari et al., 2013) reported that $\mathrm{P}_{2} \mathrm{O}_{5}$ and $\mathrm{K}_{2} \mathrm{O}$ effected significantly.

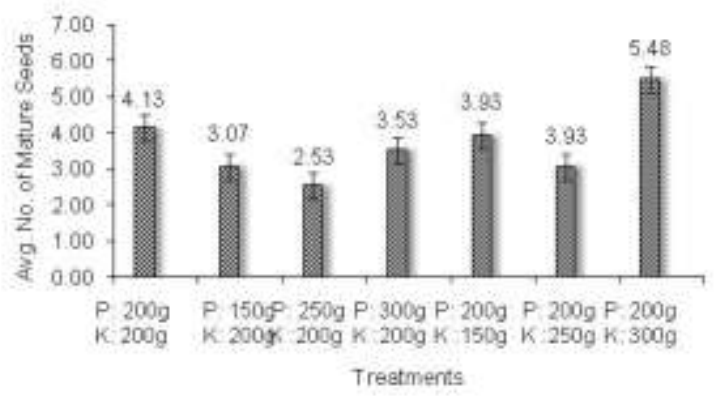

Figure 14. Effect of $P$ and $K$ on Mature seeds of kinnow fruit

Juice \%

Result regarding juice percentage revealed nonsignificant difference for treatments (Figure 15). The highest juice percentage $43.48 \%$ was observed in case of $\mathrm{T}_{5}\left(250 \mathrm{~g} \mathrm{P}_{2} \mathrm{O}_{5}+150 \mathrm{~g} \mathrm{~K}{ }_{2} \mathrm{O}\right)$. Moreover, minimum juice \% (31.19) was observed in treatment $\mathrm{T}_{7}\left(200 \mathrm{~g} \mathrm{P}_{2} \mathrm{O}_{5}+300 \mathrm{~g}\right.$ $\mathrm{K}_{2} \mathrm{O}$ ) respectively.

Our results in line with the findings of Salik et al. (2000) reported that with the application of phosphorus and potassium showed nonsignificant results regarding juice\% in Kinnow. The results confirmed the findings of Obreza and Rouse (1993) juice concentration was unaffected by fertilizer rate.

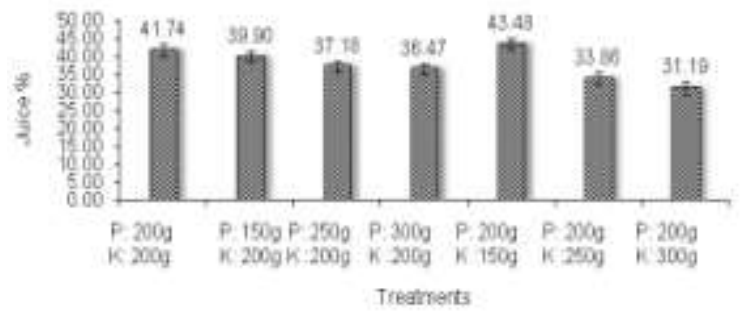

Figure 15. Effect of $P$ and $K$ on juice $\%$ of kinnow fruit

\section{Rag \%}

The fruit physical analysis profile is incomplete without the inclusion of rag weight percentage. The perusal of this table shows that the means of rag \% ranges from $16.89-28.74 \%$. Maximum rag\% was recorded in case of $\mathrm{T}_{1}\left(200 \mathrm{~g} \mathrm{P}_{2} \mathrm{O}_{5}+\right.$ $200 \mathrm{~g} \mathrm{~K}_{2} \mathrm{O}$ ) control and minimum rag $\%$ was noticed $16.89 \%$ in $\mathrm{T}_{5}\left(250 \mathrm{~g} \mathrm{P}_{2} \mathrm{O}_{5}+150 \mathrm{~g} \mathrm{~K}_{2} \mathrm{O}\right)$. 
Our findings showed non-significant results. Phosphorus and Potassium fertilizers not effected on rag\%. (Wang et al., 2006; Dudi et al., 2007 and Ashkevari et al., 2013) and) studied that the effect of phosphorous and potassium on rag\% non-significantly.

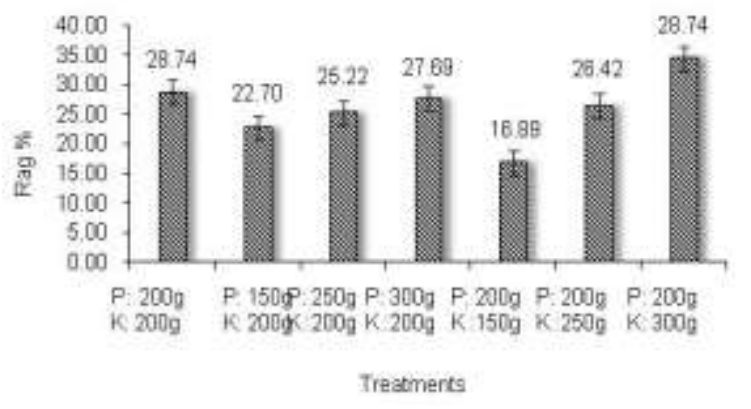

Figure 16. Effect of $P$ and $K$ on rag\% of kinnow fruit

\section{CONCLUSION}

This study unravel the effect of different combinations and doses of phosphorous and potassium fertilizers upon various parameters of young Kinnow. The verified parameters were plant height, plant spread, No. of flushes, length of flushes, No. of leaves, Leaf area index, Seed weight, Aborted seeds, Mature seed, Peel thickness, Juice \% and Rag\%. The treatment with combination of $250 \mathrm{~g} \mathrm{P}_{2} \mathrm{O}_{5}+150 \mathrm{~g} \mathrm{~K}_{2} \mathrm{O}$ and $200 \mathrm{~g} \mathrm{P}_{2} \mathrm{O}_{5}+300 \mathrm{~g} \mathrm{~K}_{2} \mathrm{O}$ is recommended to get better quality fruit.

\section{AUTHOR'S CONTRIBUTION}

Amina: Wrote up the manuscript

M. Z. Rashid: Performed laboratory and statistical analysis

M. Asim: Planed and conducted experiment

S. Shahzad: Reviewed the manuscript

S. Muqeet: Removed the Plagiarism in manuscript

\section{REFERENCES}

Abd-Allah, A. S. E. 2006. Effect of spraying some macro and micro nutrients on fruit set, yield and fruit quality of Washington Navel orange trees. Journal of Applied Sciences Research, 2 (11): 1059-1063.

Achilea, O., Y. Soffer, D. Raber and M. S. Tamim. 2002. Bonus N, P, K highly concentrated enriched potassium nitrate an optimum booster for yield and quality of citrus fruits. Acta Horticulture, 594: 461-466.

Ahmed, S., M. S. Jilani, A. Ghaffoor, K. Waseem and S. Rehman. 2001. Effect of different levels of N.P.K fertilizers on the yield and quality of Mango (Mangnifera indica L.).
Online Journal of Biological Science, 4: 256258.

Albrigo, L. G. 2002. Foliar uptake of N-P-K sources and urea biuret tolerance in citrus. Acta Horticulture, 594: 627-633.

Ali, H., Khan, M. A. and S. A. Randhawa. 2004. Interactive effect of seed inoculation and phosphorus application on growth and yield of Chickpea (Cicer arietinum). International Journal of Agriculture and Biology, 6 (1): 110-112.

Altaf, N., A. R. Khan and J. Hussain. 2008. Fruit variability in Kinnow Mandarin (Citrus reticulate Blanco.) Pakistan Journal of Botany, 40 (2): 599-604.

Alva, A. K., D. J. Mattos, S. Paramasivam, B. Patil, H. Dou and K. S. Sajwan. 2006. Potassium management for optimizing citrus production and quality. International Journal of Fruit Science, 6: 3-43.

Anonymous. 2017 and 2018. Fruit, vegetables and condiment statistics of Pakistan, Govt. of Pakistan, Ministry of Food, Agriculture and Live Stock (Economic Wing) Islamabad, pp. 1-2.

Ashkevari, A. S., S. H. Hoseinzadeh and M. Miransari. 2013. Effects of different nitrogen, phosphorus, potassium rates on the quality and quantity of citrus plants, variety Thomson novel under rainfed and irrigated conditions. Journal of Plant Nutrition, 36 (9): 1412-1423.

Ashraf, M. Y., A. Gul, M. Ashraf, F. Hussain and G. Ebert. 2010. Improvement in yield and quality of Kinnow (Citrus deliciosa x Citrus nobilis) by potassium fertilization. Journal of Plant Nutrition, 33 (11): 1625-1637.

Ashraf, M. Y., F. Hussain, M. Ashraf, J. Akhter and G. Ebert. 2012. Modulation in yield and juice quality characteristics of citrus fruit from trees supplied with zinc and potassium foliarly. Journal of Plant Nutrition, 36 (13): 1996-2012.

Barakat, M. R., T. A. Yehia and B. M. Sayed. 2012. Response of Newhall Naval Orange to bio-organic fertilization under newly reclaimed area conditions: vegetative growth and nutritional status. Journal of Horticulture Sciences and Ornamental Plant, 4 (1): 18-25.

Davies, F. S. and L. G. Albrigo. 1994a. Citrus. CAB International, Wallingford, UK.

Davies, F. S. and L. G. Albrigo. 1994b. Environmental Constraints on Growth, Development and Physiology of Citrus. In: 
F.S. Davies and L.G. Albrigo (Eds.), Citrus, CAB Int. Wallingford, UK. Pp. 51-82.

Dubey, A. K. and D. S. Yadav. 2003. Response of Khasi Mandarin (Citrus reticulate Blanco) to organic versus inorganic fertilization. Indian Journal of Agriculture Research, 3: 214-218.

Dudi, O. P., R. P. Singh, S. Singh and S. Baloda. 2007. Effect of phosphorus and Potassium application on growth, yield and quality of Kinnow mandarin. Haryana Journal of Horticulture Science, 3: 203-204.

Hammami, A., H. Rezgui and R. Hellali. 2010. Leaf nitrogen and potassium concentrations for optimum fruit production, quality and biomass tree growth in Clementine mandarin under Mediterranean climate. Journal of Horticulture Forest. 2: 161-170.

Ibe, R. B., I. O. Lawal and A. A. Olaniyan. 2011. Economic Analysis of Yields of Citrus as Influenced by Organo-Mineral Fertilizer Treatments in Ibadan, Southwest Nigeria. World Journal of Agricultural Sciences, 7 (4): 425-429.

Ibrahim, M., N. Ahmad, S. A. Anwar, T. T. Majeed and M. I. Asghar. 2004. Micronutrient effects on citrus-fruit yield growing on calcareous soils. Proceedings of symposium on "Plant-nutrition management for horticultural crops under water-stress conditions. (Eds.): Soil Science Society of Pakistan at Agricultural Research Institute Sariab, Quetta, Pakistan. pp. 95-100

Khan, F. U., N. Khan and F. Anjum. 2016. Farmers perception about yield losses of kinnow (Citrus reticulate) during its harvesting and post harvesting operations: $A$ case study of tehsil Sargodha, Pakistan. Journal of Rural Development and Agriculture, 1 (1): 12-19.

Lester, G. E., J. L Jifon and D. J. Makus. 2010. Impact of potassium nutrition on food quality of fruits and vegetables: a condensed and concise review of the literature. Better Crop, 94: 18-21.

Liu, G., C. Jiang, Y. Wang S. Peng and L. Lu. 2010. A review on effects of mineral nutrients on citrus. China Journal of Soil Science, 41: 2006-2045.

Liu, K., F. Huihua, B. Qixin and S. Luan. 2000. Inward potassium channel in guard cells as a target for polyamine regulation of stomatal movements. Plant Physiology, 124 (3): 1315-1326.
Niaz, C. M. 2004. History and origin of Citrus fruits. Proc. Int Symp. Citric. Agriculture Foundation Pakistan, Islamabad, 7-10.

Obreza, T. A. 2001. Effects of $\mathrm{P}$ and $\mathrm{K}$ fertilization on young citrus tree growth. UFIFAS, Soil and Water Science Department of Extension Pub. SL.185.

Obreza, T. A. and R. E. Rouse. 1993. Fertilizer effects on early growth and yield of Hamlin orange trees. Horticulture Science, 2: 111114.

Raza, T., M. Ibrahim and M. Amjad. 1999. Seasonal changes in mineral nutrient and seed oil in Kinnow fruit (Citrus reticulate Blanco). International Journal of Agriculture and Biolilolgy, 1: 339-341.

Saeed, B., H. Gul, S. Wahab, Y. Durrani, B. Haleema, M. Ayub, A. Muhammad, A. Said and I. Ahmed. 2011. Effect of phosphorus and potassium on seed production of berseem. African Journal of Biotechnology, 63: 13769-13768.

Salik, M. R., F. Muhammad and A. Shakir. 2000. Effect of time of fertilizer application on the productivity of Kinnow (Citrus reticulate Blanco). Pakistan Journal of Biological Science, 9: 1375-1376.

Shirgure, P. S. and A. K. Srivastava. 2013. Plant growth, Leaf Nutrient status, fruit yield and quality of Nagpur mandarin (Citrus reticulate Blanco) as influenced by potassium (K) fertigation with four potash fertilizer sources. S. J. of Crop Science. 3: 36-42.

Singh, K., K. L Jamwal, J. S. Bohra and S. Kalyan. 1983. Effect of phosphorus and biofertilizer on growth, yield and quality of chickpea (Cicer arietinum L.).Trans. Indian Soc. Desert Technol. and Univ. Centre of Desert Studies, 8: 33.

Smith, M. W., B. Cheary and B. Carroll. 1995. Time of nitrogen application and Phosphorus effects on growth, yield, and fruit quality of pecan. Horticulture Science, 3: 532-534.

Srivastava, A. K. and S. Singh. 2009. Citrus decline soil fertility and plant nutrition. Journal of Plant Nutrition, 32 (2): 197-245.

Srivastava, A. K., P. S. Shirgure and S. Singh. 2006. Differential fertigation response of Nagpur mandarin (Citrus reticulata Blanco.) on an alkaline inceptisol under sub-humid tropical climate. Tropical Agriculture, 2: 97104.

Storey, R. and M. Treeby. 2002. Cryo-SEM study of early symptoms of peteca spot in 
Lisbon lemon. Journal of Horticultural Science and Biotechnology, 5: 551-556.

Tahir, A. 2014. Forecasting citrus exports in Pakistan. Pakistan Journal of Agricultural Research, 27: (1): 64- 68.

Tariq, M., M. Sharif, Z. Shah and R. Khan. 2007. Effect of foliar application of micronutrients on the yield and quality of sweet orange (Citrus sinensis L.). Pakistan Journal of Biology Science, 10 (11): 1823-1828.

Tiwari, K. N. 2005. Diagnosing potassium deficiency and maximizing fruit crop production. Better Crop, 89: 29-31.

Umar, M., S. M. Zia-ul-Hassan and W. A. Dogar. (2017). Citrus and its Post-harvest losses. Weekly Technology Times, August 21. https://www.Technology times.pk/citrusand-its-post-harvest-losses-2.

Wang, R., S. Xue-gen, W. Y. Zhang, Y. Xiao-e and U. Juhani. 2006. Yield and quality responses of citrus (Citrus reticulate) and tea (Podocarpus fleuryi Hickel.) to compound fertilizers. Journal Zhejiange University, (China) 7: 696-701.

Yahiya, M., Samiullah and A. Fatima. 1995. Influence of phosphorus on nitrogen fixation in chickpea cultivars. Journal of Plant Nutrition, 18 (4): 719-727.

Zaied, S., S. A. A. Khafagy and M. A. Saleh. 2006. Effect of nitrogen and potassium fertilization on vegetative growth, fruit set and quality of Washington navel orange trees. Journal of Applied Sciences Research, 11: 851-857.

Zaman, Q. and A.W. Schumann. 2006. Nutrient management zones for citrus based on variation in soil properties and tree performance. Precision Agriculture, 7: 45-63.

(Received: January 07, 2021; Accepted: May 13, 2021) 